\title{
Suomalais-ugrilaiset kielet ja internet -projekti 2013-2019
}

\author{
Tommi Jauhiainen ${ }^{1,2}$ [0000-0002-6474-3570] \\ Heidi Jauhiainen ${ }^{1[0000-0002-8227-5627]}$ \\ Krister Lindén ${ }^{10000-0003-2337-303 X]}$ \\ 1 Digitaalisten ihmistieteiden osasto, Helsingin yliopisto \\ \{etunimi, sukunimi\}@helsinki.fi \\ 2 Department of English, Rochester Institute of Technology
}

\begin{abstract}
Tiivistelmä Tässä artikkelissa esittelemme vuonna 2013 aloittaneen ja 2019 päättyneen Koneen säätiön rahoittaman Suomalais-ugrilaiset kielet ja internet projektin suunnittelua sekä toteutusta ja kokoamme yhteen saavutettuja tuloksia. Aikaisemmin julkaistujen valmiiden tulosten lisäksi esittelemme myös joitakin keskeneräisiksi jääneitä tuotoksia. Projektissa kerättiin verkkoharavoinnin ja automaattisen kielentunnistuksen avulla harvinaisilla uralilaisilla kielillä kirjoitettujen sivujen tekstiä avoimilta verkkosivuilta. Projektissa kehitetty Wanca-portaalisivusto toimii kokoelmana linkkejä haravoinnin yhteydessä löydetyille näitä kieliä käyttäen kirjoitetuille sivuille. Projektissa kehitettiin prosessi, jota käyttäen verkkoharavan avulla löydetyistä teksteistä muodostetaan virkekorpuksia halutuille kielille. Muodostetut virkekorpukset ovat avoimesti saatavilla FIN-CLARIN konsortion ylläpitämän Kielipankin Korp-palvelussa. Verkkoharavoinnin ja korpusten kokoamisen ohella projekti keskittyi erityisesti kielentunnistuksen menetelmien kehittämiseen, jossa saavutettiin kansainvälisesti erittäin merkittäviä tuloksia. Projektin tutkijat ovat osallistuneet kansainvälisiin tekstin kielentunnistukseen keskittyneisiin kilpailuihin ja voittaneet niistä useita.
\end{abstract}

Keywords: Verkkoharavointi · Kielentunnistus · Uralilaiset kielet.

\section{Johdanto}

Koneen Säätiö oli vuonna 2011 palkannut Jack Rueterin valmistelemaan uhanalaisiin uralilaisiin kieliin keskittyvää kieliohjelmaa. Seuraavana vuonna säätiö julkaisi nelivuotisen kieliohjelmansa 2012-2016, ${ }^{3}$ jonka kautta oli tarkoituksena rahoittaa erityisesti uhanalaisiin suomalais-ugrilaisiin kieliin keskittyvää tutkimusta [33]. Kieliohjelman päätavoitteena oli edistää pienten suomalais-ugrilaisten kielten, suomen ja Suomen vähemmistökielten dokumentointia ja yleisesti vahvistaa niiden asemaa.

\footnotetext{
${ }^{3}$ https://www.koneensaatio.fi/wp-content/uploads/Kieliohjelma.pdf
} 


\section{Projektin suunnittelu}

Idea tässä artikkelissa esiteltyyn hankkeeseen syntyi Koneen Säätiön kieliohjelman suuntauksista, Tommi Jauhiaisen aikaisemmasta kielentunnistuksen tutkimustyöstä ${ }^{4}$ sekä T. Jauhiaisen kokemuksista Kansalliskirjaston verkkojulkaisujen keräämiseen liittyen. Alun perin T. Jauhiaisen idea kielentunnistuksen tutkimiseen oli syntynyt ajatuksesta kerätä internetistä suomenkielisiä virkkeitä, lauseita tai sanoja ja muodostaa näistä vapaasti saatavilla olevia tekstikorpuksia erityisesti kieliteknologian kehityksen tarpeisiin. Myös tämän projektin tavoitteena oli jo heti alusta alkaen kerätä nimenomaan virkekorpuksia, sillä virkkeitä pidempiä tekstejä internetistä on ongelmallista koostaa korpuksiksi koska tekstit saattavat ylittää teostason, jolloin niitä suojaa tekijänoikeuslaki ja niiden edelleenjakaminen ilman lupaa olisi lainvastaista.

Projektin kantavana ideana oli kielentunnistinta käyttäen rakentaa järjestelmä, joka automaattisesti internetiä tutkien keräisi sieltä halutunkielistä, tässä tapauksessa suomalais-ugrilaista, aineistoa virkekokoelmiksi ja lisäksi kirjaisi löytämänsä sivustot. Virkekokoelmat tai -korpukset toimisivat tutkimusaineistona erityisesti kielentutkijoille ja suomalais-ugrilaisten kielten ja kulttuurien tutkimukselle. Sivustolistauksista olisi mahdollista rakentaa portaalisivustoja pienemmille kielille, jotka voisivat parantaa linkitettyjen verkkosivustojen saavutettavuutta ja siten edesauttaa kielten käyttäjiä löytämään toisensa ja näin ylläpitämään yhteistä kielellistä kulttuuriaan.

T. Jauhiaisen tutkimustyö oli ennen projektia keskittynyt erityisesti digitaalisessa muodossa olevan tekstin kielen automaattiseen tunnistamiseen. Kielen tunnistaminen on kieleltään tuntemattoman tekstin vertaamista joukkoon riittävällä varmuudella kieleltään tunnettuja tekstejä. Samoja tai hyvin läheisiä menetelmiä voidaan käyttää myös tekstin lajitteluun esimerkiksi aihealueiden suhteen. Hän oli kirjoittanut tutkimustyönsä pohjalta pro gradu -tutkielman "Tekstin kielen automaattinen tunnistaminen"[15]. Tutkielma oli syntynyt osana Suomen Kansalliskirjaston verkkojulkaisujen keräämisen, eli verkkoharavoinnin, ${ }^{5}$ kehitystyötä. Tutkielman ohella hän oli rakentanut kielentunnistimen, joka kykeni erottelemaan tekstin kielen 103 kielen joukosta. Kielentunistimen käyttämät kielimallit oli luotu käyttäen Wikipediassa sijaitsevien erikielisten artikkelikokoelmien tekstimassasta muodostettuja tekstikorpuksia. Gradututkimuksen testien perusteella kielentunnistin pystyi tunnistamaan Suomen kielen oikein $95,5 \%$ todennäköisyydellä jo 10 merkin mittaisesta tekstinäytteestä. Suomen lähisukulaisista 103 kielen joukossa olivat ainoastaan viro ja unkari.

Rakennettu kielentunnistin oli ollut tarkoitus ottaa käyttöön Kansalliskirjaston verkkoharavoinnissa laajemmin, mutta käytännössä kielentunnistimen yhdistäminen verkkoharavaan ei ollutkaan suoraviivaista. Pro gradu- tutkielman tunnistinta rakennettaessa tutkittiin muutaman algoritmin ja kielimallien eri yhdistelmiä ja tehtiin kattavia evaluointeja näiden välillä. Väitöstutkimuksessa oli tarkoituksena tehdä aiemman kartoituksen pohjalta tarkempi ja laajempi sel-

\footnotetext{
${ }^{4}$ http://urn.fi/URN:NBN:fi-fe201012223157

${ }^{5}$ http://hdl.handle.net/10138/171893
} 
vitys käytettävissä olevista menetelmistä tuoreimman kansainvälisen tutkimuksen valossa. Selvitykseen suunniteltiin koottavan kattava lista olemassa olevista kielentunnistamisen menetelmistä ja kielentunnistimista.

T. Jauhiaisen väitöskirjatyö kielen tunnistamisesta oli alkanut syksyllä 2011 ja työn ensimmäisessä vaiheessa oli Wikipedian artikkelikokoelmista muodostettu lisää tekstikorpuksia, joista kielentunnistimen uudelle versiolle oli tarkoitus rakentaa uudet ja paremmat kielimallit. Projektin alkaessa tekstikorpuksia oli muodostettu jo 264 kielelle, joiden joukossa kieliohjelman kannalta kiinnostavia kieliä olivat suomi, viro, unkari, komipermjakki, komi, mokša, niittymari, vuorimari, ersä, pohjoissaame, udmurtti, vepsä sekä võru.

Kielentunnistimen tunnistustuloksia pyrittiin parantamaan hyödyntäen kielentunnistimen kannalta uusia menetelmiä. Aikaisemmin käytettyjä menetelmiä oli suunniteltu jatkokehitettävän esimerkiksi ottamalla huomioon myös sanarajat ylittävä informaatio, joka pro gradu -tutkielman tunnistimessa oli kokonaan jätetty huomiotta. Samoin oli tarkoitus tutkia mahdollisuutta laskettuihin kirjainyhdistelmiin perustuvien lukujen parempaan hyödyntämiseen kielen päättelyssä käyttäen esimerkiksi koneoppimisessa käytettyjä vakiomenetelmiä. Uusia menetelmiä tai niiden yhdistelmiä käyttävien tunnistinten tunnistustuloksia piti vertailla toisiinsa ja niiden joukosta valita parhaiten testeissä menestyvä menetelmä internet-haravoinnin käyttöön.

Haravointijärjestelmässä suunniteltiin keskityttävän prototyypin rakentamiseen, mutta heti alussa tunnistettiin että järjestelmän tehokkuusvaatimusten saavuttaminen vaatii tutkimusta myös tietoliikennetekniikoiden (http- ja tcp/ipprotokollien) ja tietorakenteiden optimoidusta käyttämisestä.

Hanke toteutettiin Helsingin yliopiston Nykykielten laitoksella osana kansainvälistä CLARIN yhteistyötä, jota Suomessa edusti ja edustaa FIN-CLARINkonsortio. ${ }^{6}$ Yhtenä FIN-CLARINin tavoitteena on varmistaa, että kaikki Suomen tutkijat pääsevät mahdollisimman helposti käyttämään mitä tahansa eurooppalaisia CLARIN-yhteensopivia kieliaineistoja, ja että ulkomaalaisille tutkijoille tarjotaan vastaavat mahdollisuudet suomalaisiin aineistoihin. Hankkeen osana tehtävässä korpustutkimuksessa hyödynnettiin sekä CLARINin Virtual Language Observatoryn ${ }^{7}$ että META-NET hankkeen META-SHARE-varannon ${ }^{8}$ tietoja erilaisista kieliresursseista.

\section{Tavoitteet ja tulokset}

Tässä luvussa käymme tarkemmin läpi projektille alunperin asetettamiamme tavoitteita ja peilaamme niitä toteutuneisiin tuloksiin.

Suomalais-ugrilaiset kielet ja internet -hankkeen vastuullisena johtajana toimi FIN-CLARINin tutkimusjohtaja Krister Lindén. Alkuperäinen hankesuunnitelma oli tehty neljäksi vuodeksi alkaen vuoden 2013 alusta. Projektin työntekijöinä Koneen säätiön henkilökohtaisten apurahojen turvin toimivat Tom-

\footnotetext{
${ }^{6}$ https://www.kielipankki.fi/organisaatio/

${ }^{7}$ https://vlo.clarin.eu

${ }^{8}$ https://metashare.csc.fi
} 
mi ja Heidi Jauhiainen. Hankkeen rahoitus alkoikin vuoden 2013 alusta, mutta kokonaiskestoltaan nelivuotisen projektin viimeinen apuraha maksettiin vasta vuoden 2019 tammikuussa. Projektin aikataulu pitkittyi, kun T. Jauhiaisen oli Kansalliskirjaston työtilanteen vuoksi palattava Kansalliskirjaston tietojärjestelmäpäälliköksi keväällä 2016. Heidi Jauhiainen aloitti syyskuussa 2016 Suomen Akatemian rahoittamassa projektissa Semantic Domains in Akkadian Texts, ${ }^{9}$ ja sekä T. että H. Jauhiainen pääsivät palaamaan Suomalais-Ugrilaiset kielet ja internet -projektin pariin vasta talvella 2017-2018. Osin näistä viivästyksistä johtuen jotkin projektin tärkeimmistä tuloksista julkaistiin vasta elokuussa 2019. Projektiin selvästi liittyviä tuloksia on julkaistu myös vielä vuosina 2020 ja 2021.

Hankkeessa oli tarkoituksena rakentaa prototyyppi järjestelmästä, jonka avulla olisi mahdollista ylläpitää linkkisivustoa harvinaisilla suomalais-ugrilaisilla kielillä kirjoitettua tekstiä sisältäville sivustoille. Linkkikokoelmalla pyrittäisiin vahvistamaan suomalais-ugrilaisten kielten asemaa ja edesauttamaan kielten käyttämistä kieliyhteisöjen hajotessa.

Yhtenä projektin päätarkoituksena oli kerätä avoimilta verkkosivuilta pienillä uralilaisilla kielillä kirjoitettua tekstiä. Projektin alussa H. Jauhiainen vertaili erilaisia verkkoharavoinnin menetelmiä ja projektissa päädyttiin käyttämään avoimen lähdekoodin verkkoharavaa Heritrixiä, ${ }^{10}$ joka on myös Kansalliskirjaston käytössä. Tekniseltä toteutukseltaan järjestelmä on Kansalliskirjaston käyttämän verkkoharavointijärjestelmän sukulainen, mutta järjestelmät erosivat erityisesti siinä, että hankkeessa rakennettavan prototyypin ei ollut tarkoituskaan tallentaa kaikkia löytämiään sivustoja. Hankkeessa oltiin myös kiinnostuneita ainoastaan tekstimateriaalin keräämisestä. Iso osa Kansalliskirjaston verkkoharavan käyttämästä ajasta ja tallennustilasta kuluu erilaisten binääritiedostojen, kuten kuvien ja videoiden, keräämiseen. Myös html-kielisellä sivulla varsinaisen tekstimateriaalin koko on usein vain murto-osa koko tiedoston koosta.

\subsection{Laskentaympäristö}

Järjestelmän arvioitiin tarvitsevan toimiakseen tehokkaan palvelinympäristön, runsaasti tallennustilaa sekä nopeat verkkoyhteydet ja hanke sisälsi myös tarvittavan palvelininfrastruktuurin suunnittelun ja hankinnan. Järjestelmän laajamittaisen käytön vaatimaa palvelin- ja verkkokapasiteettia oli vaikeata ennustaa etukäteen ja sen selvittäminen jäikin yhdeksi hankkeen aikana tutkittavista tietoteknisistä kysymyksistä. Haravointijärjestelmän rakentaminen ja järjestelmän käyttämien menetelmien tutkiminen aloitettiin vuoden 2013 alkupuoliskolla.

Hankkeen verkkoharavointia suorittavan järjestelmän tarkoitus oli kyetä käymään lävitse mahdollisimman paljon internetistä löytyviä sivustoja löytääkseen suomalais-ugrilaisilla kielillä kirjoitetut sivut mahdollisimman kattavasti. Hankkeessa suoritettu haravointi eroaa aiemmin esille tulleesta Kansalliskirjaston

\footnotetext{
${ }^{9}$ https://researchportal.helsinki.fi/en/projects/semantic-domains-in-akkadian-texts

${ }^{10}$ https://github.com/internetarchive/heritrix3/wiki
} 
verkkoharavoinnista, mutta hankkeen päämäärä oli laajuudeltaan yhtä kunnianhimoinen, koska tarkoituksena oli haravoida myös Suomen ulkopuolella sijaitsevaa internettiä. Kansalliskirjaston verkkoharavointiin käyttämiä palvelimia voitiinkin käyttää esimerkkinä määriteltäessä hankkeen palvelintarpeita. Tuolloinen Kansalliskirjaston verkkoharavointia suorittava palvelin oli vuonna 2009 hankittu kaksi neliydinprosessoria ja 42 gigatavua muistia omaava fyysinen palvelin. Toinen identtinen palvelin toimi haravoidun aineiston käyttöönasettamisessa ja fyysisten palvelinten lisäksi käytössä oli useita virtuaalipalvelimia. Kansalliskirjaston verkkoharavointiin käyttämät palvelimet sijaitsivat Helsingin yliopiston tietotekniikkakeskuksen konesalissa, jossa niiden laitteistoja ylläpiti teknologiapalveluiden palvelinylläpitoryhmä. T. Jauhiainen oli suunnitellut myös Kansalliskirjaston palvelinhankinnat ja hänen aikaisempaan kokemukseensa perustuen myös tämän hankkeen palvelimet sijoitettiin Helsingin yliopiston konesaliin.

Palvelimia suunniteltiin tarvittavan 2 kappaletta. Ensimmäinen toimisi erityisesti kielentunnistimen ja sen kehitystyön ympäristönä ja toinen verkkoharavoinnin, korpusten keräämisen ja linkkisivustojen rakentamisen ympäristönä. Palvelinten kapasiteettitarpeet määriteltiin seuraavasti:

- ainakin 2 prosessoria ja 8 ydintä

- ainakin 64 gigatavua keskusmuistia

- ainakin 10 teratavua levytilaa, josta osa nopeaa Flash-levyä

Ensimmäiset palvelimet, nimeltään suki1 ja suki2, tilattiin välittömästi projektin rahoituksen varmistuttua vuoden 2012 lopulla ja ne saapuivat yliopiston konesaliin jo 2013 tammikuun puolessa välissä. Molemmat palvelimet oli varustettu kahdella kuusiytimisellä Xeon prosessorilla, 256 gigatavulla keskusmuistia sekä 2,5 teratavulla levytilaa. Helsingin yliopiston onnistuneiden kilpailutusten johdosta ja osin Kansalliskirjaston tuella oli mahdollista laajentaa projektin palvelinperhettä vuotta myöhemmin kahdella palvelimella. Tulevia laajamittaisia haravointeja ajatellen ensimmäinen uusista palvelimista, suki3, määriteltiin erityisesti tallennuspalvelimeksi ja se sisälsikin 20 teratavua tallennustilaa, jota jaettiin suki1- ja suki2-palvelinten sekä uuden haravointipalvelimen, suki4:n, käyttöön. Uusi järeä haravointipalvelin sisälsi teratavun verran nopeaa Flashlevyä, 512 gigatavua keskusmuistia sekä 64 laskentaydintä. Palvelinten avulla oli mahdollista ladata ja tunnistaa kieli noin 400 sivulta sekunnissa. Aineiston karttuessa projektin aikana hankittiin vielä myöhemmin toinen tallennuspalvelin, suki5, joka toi projektille toiset 20 teratavua tallennustilaa. Projektin palvelimet toimivat työvälineinä myös joillekin yhteistyökumppaneille toimien esimerkiksi Mediawikin testialustana Jack Rueterin Wiki-pohjaiselle sanakirjalle [36]. Palvelimista suki1, suki2 sekä suki5 ovat edelleen FIN-CLARIN infrastruktuurin aktiivisessa käytössä palvellen esimerkiksi Vaikuttavuussäätiön rahoittamaa "Language Identification of Speech and Text" -hanketta ${ }^{11}$ sekä Muinaisen Lähiidän imperiumit -huippuyksikköä. ${ }^{12}$

${ }^{11}$ https://www.vaikuttavuussaatio.fi/rahoitettavat-hankkeet/

${ }^{12}$ https://www.helsinki.fi/fi/tutkimusryhmat/muinaisen-lahi-idan-imperiumit 


\subsection{Verkkoharavointia}

Vuoden 2013 aikana H. Jauhiainen kirjoitti tietojenkäsittelytieteen kandidaatintutkielman verkkoharavoinnin menetelmistä [11]. ${ }^{13}$ Jotta Heritrix paremmin ohjautuisi automaattisesti uralilaisia kieliä sisältäville sivustoille, sen piti kyetä päättelemään sivun kieli jo haravoinnin aikana. Tätä varten H. Jauhiainen kehitti Heritrixistä useita versioita, jotka eristivät kerätyistä sivuista mahdolliset tekstiä sisältävät osiot ja kykenivät keskustelemaan erillisen kielentunnistuspalvelun kanssa. Haravointijärjestelmästä oli käytettävissä prototyyppi vuoden 2014 alusta, jolloin voitiin aloittaa laajamittaiset testiharavoinnit internet-ympäristössä.

Vuosina 2014 ja 2015 pienillä uralilaisilla kielillä kirjoitettuja tekstejä etsittiin sellaisten kansallisten verkkotunnusten alta, joilta uskottiin kyseisiä sivuja löytyvän (.ee, .fi, .hu, .lv, .no, .se ja .ru), sekä lisäksi .com-domainista. Kansalliskirjaston kanssa tehdyn yhteistyön tuloksena löydettiin tekstejä myös joistakin muista domaineista. Erilaisia verkkoharavointeja suoritettiin myös 2016, 2017 ja 2018. Suomessa projektia esiteltiin useissa seminaareissa ja kokouksissa 20132017. Projektia ja sen tekemiä haravointeja esiteltiin kansainvälisesti vuosina 2014 ja 2015. Vuonna 2014 T. Jauhiainen esitteli kielentunnistukseen liittyvää tutkimustaan Oslossa järjestetyssä "Web-Scale Natural Language Processing in Northern Europe" -työpajassa, ${ }^{14}$ jossa luotiin yhteyksiä mm. Common Crawl säätiöön. ${ }^{15}$ Vuoden 2015 alussa H. ja T. Jauhiainen esittelivät projektia ensimmäisessä kansainvälisessä "Computational Linguistics for Uralic Languages" -työpajassa ${ }^{16}$ (IWCLUL 2015) Tromssassa posterin ja siihen liittyvän artikkelin voimin [12]. Työpajan ohessa luotiin yhteyksiä Tromssan yliopiston Giellatekno -tutkimusryhmään ja tutustuttiin heidän toimintaansa. ${ }^{17}$ Myöhemmin samana vuonna T. Jauhiainen kutsuttiin esittelemään projektia Viron kansalliskirjastossa järjestettyyn "Web Archiving: Preserving the History of Data-Driven Society" -tapahtumaan, ${ }^{18}$ Tallinnaan.

Julkaisuperinteen siirtyminen internetiin on nostanut internetin keräämisen talteen maailman kansalliskirjastojen tärkeimpien tehtävien joukkoon. ${ }^{19}$ Kansalliskirjastot haluavat kerätä nimenomaan omien kansalaistensa tuotoksia, jotka monessa tapauksessa pystytään erottelemaan käytetyn kielen perusteella.

Projektin aikana Kansalliskirjastolle tehtiin erillistä korvausta vastaan useita haravointeja suomenkielisten sivujen löytämiseksi. Projektia sekä Kansalliskirjaston kanssa tehtyä yhteistyötä esiteltiin verkkoarkistointiin erikoistunees-

13 http://www.suki.ling.helsinki.fi/Jauhiainen_Verkkoharavoinnin_menetelmia.pdf

14 https://researchportal.helsinki.fi/en/activities/web-scale-natural-languageprocessing-in-northern-europe-workshop

15 https://commoncrawl.org

${ }^{16}$ https://web.archive.org/web/20160331185349/http://gtweb.uit.no/iwclul2015/

17 https://giellatekno.uit.no

18 https://researchportal.helsinki.fi/en/activities/web-archiving-preserving-thehistory-of-data-driven-society

19 https://blogs.helsinki.fi/digikirjasto/2015/02/12/tallinkilla-tallinnaanverkkoarkistoinnin-varjolla/ 
sa konferenssissa Lontoossa 2017 (IIPC Web Archiving Conference, Lontoo). ${ }^{20}$ Vuonna 2015 tehtiin yhteistyötä myös Viron Kansalliskirjaston kanssa vironkielisten sivujen löytämiseksi.

Common Crawl säätiön keräämä ja avoimesti tarjoama maailmanlaajuisen haravoinnin tuloksena tehty korpus ajettiin kielivalikoiman tunnistimen lävitse, minkä avulla löydettiin relevantteja tekstejä myös muiden verkkotunnusten alueilta. Helmikuussa 2015 projektin siihen mennessä löytämät verkko-osoitteet toimitettiin Common Crawl säätiölle, jotta projektin haravoimat, Common Crawlin korpuksesta puuttuvat, sivustot tallentuisivat tuleviin versioihin Common Crawl korpusta.

\subsection{Wanca}

Linkkisivuston suunnittelemisessa oli ajatuksena käyttää suomalais-ugrilaisten kielten ja kulttuurien asiantuntijoita verkkosivujen sisällön laadun tutkimisessa ja suunnitella siihen myös kansalaistiedettä tai talkoistamista hyödyntäviä ominaisuuksia. Hyvinkin laajojen automaattisesti kerättyjen linkkilistojen tarkistustyö onnistuisi vain kielenkäyttäjiä osallistamalla. H. Jauhiainen rakensi Wancaksi ${ }^{21}$ nimetyn yhteistyöportaalin, joka julkistettiin vuonna 2015 kansainvälisen fennougristikongressin yhteydessä (CIFU XII, Oulu). ${ }^{22}$ Wancaa käyttäen eri kielten asiantuntijoilla on mahdollisuus tutkia linkkien takana olevia sivuja, äänestää automaattisen kielentunnistuksen oikeellisuudesta ja muuttaa tarvittaessa linkin kieltä. Monet asiantuntijat, mm. Jack Rueter, avustivat projektin jäseniä linkkien kuratoinnissa.

Monien verkkosivujen sisältö on nykyään dynaamista ja se vaihtuu joskus jopa tunnista toiseen. Monet Wancan sisältämät linkit johtavat esimerkiksi uutissivustoihin, joiden sisältö ei enää lainkaan vastaa sitä mitä projektissa aikoinaan ladattiin. Jopa staattiset sivut muuttuvat aika ajoin. Sivustorakenteita uudistetaan ja erinäisistä syistä jotkut sivustot katoavat kokonaan internetistä. Wanca saattaa säilyttää joitain sivuja, joihin ei ehkä enää ole linkkejä missään muualla, mutta monet Wancassa olevat linkit ovat jo vanhentuneita.

Wancan linkkilistasta voi kieltä osaamatonkin nähdä, että kielille, joilla on internetissä vain muutamia sivustoja, on usein sivustoja, joiden tarkoituksena on kielen elvyttäminen tai säilyttäminen ja joita ylläpitävät yhteisöt tai yliopistot. Kielillä, joilla on enemmän sivustoja, löytyy myös uutissivustoja ja jopa kaupallisia sivuja. Pohjoismaissa, erityisesti Ruotsissa, löytyy viralliset viranomaissivustot vähemmistökielillä, myös saamen kielillä ja meänkielellä. Tämä ei tunnu olevan yhtä yleistä Venäjällä puhutuissa kielissä.

Teimme vuonna 2017 suoritetun Wancan linkkien tarkistuslatauksen yhteydessä pientä tutkimusta siitä, miten harvinaisilla uralilaisilla kielillä kirjoitetut sivustot linkittyvät toisiinsa. Olimme optimoineet Heritrixin niin, että harvinaisilla uralilaisilla kielillä kirjoitetuilta sivuilta löydetyt linkit ovat etuasemassa

\footnotetext{
${ }^{20}$ https://netpreserve.org/wac2017/abstracts/\#_abstract83

${ }^{21}$ http://suki.ling.helsinki.fi/wanca/

22 https://blogs.helsinki.fi/fennougrica/2015/08/19/cifu-xii-day-3/
} 
muihin linkkeihin nähden kun valitaan mitä ladataan seuraavaksi. Jos relevantit sivustot linkittyvät toisiinsa, sen pitäisi näkyä aineistossamme, vaikka emme todennäköisesti pystyneet täydellisesti haravoimaan valitsemiamme kansallisia verkoavaruuksia. Käsittelimme samalla sivustolla olevia erikielisten sivujen ryhmiä eri entiteetteinä. Visualisoimme linkittyvien sivusto-kieli parien verkon Gephityökalun $^{23}[3]$ avulla. Verkosto on nähtävissä Suki-projektin kotisivuilla ${ }^{24}$ interaktiivisessa graafien katselukäyttöliittymässä. ${ }^{25}$ Verkostossa sivustojen väliset linkit muodostavat pääasiassa kahdenlaisia ryhmiä. Ensinnäkin yhden sivuston sisällä olevat erikieliset sivut linkittyvät usein toisiinsa. Tässä ryhmässä linkittyvät sivustot on yleensä kirjoitettu hyvin läheisillä kielillä. Toisessa ryhmässä samalla kielellä kirjoitetut täysin erilliset sivustot sisältävät toisinaan linkkejä toisiinsa. Toki on myös sivustoja, jotka sisältävät molempia edellämainituista linkkityypeistä. Tietyt sivustot, kuten giellatekno.no, samediggi.fi ja davvi.no, ovat keskeisiä saamen kielten säilyttämisen ja elvyttämisen kannalta, ja ne linkittyvät myös toisilla kielillä kirjoitettuihin sivuihin muilla sivustoilla. Samanlaisia sivustoja ei näytä olevan Venäjällä puhuttujen uralilaisten kielten osalta.

Wancan linkkilistaa on käytetty mm. Kansalliskirjaston vuoden 2019 saamelaiskielisiin sivuihin kohdistuneessa teemakeräyksessä. ${ }^{26}$ Prototyypin lähdekoodi oli tarkoitus julkaista avoimen lähdekoodin lisenssillä GitHubin kautta ja näin myös tehtiin vuoden 2019 loppupuoliskolla. ${ }^{27}$

\subsection{Kielentunnistin}

Hankkeessa oli tarkoitus toteutettaa tekstin kielen automaattinen tunnistin erityisesti verkkoharavoinnin tarpeisiin. Tekstin kielen automaattinen tunnistaminen oli internetissä olevan tekstimäärän ja kielivalikoiman kasvaessa tullut tärkeäksi näiden dokumenttien automaattisen käsittelyn esivaiheeksi. Tekstin kieli on tarpeellista tunnistaa, jotta tekstiä voidaan käsitellä oikeilla kieliteknologisilla välineillä. Esimerkiksi hakukoneiden verkkosivujen indeksointimenetelmät saattavat olla riippuvaisia indeksoitavan kielen tunnistamisesta. Verkkosivujen tekijät eivät välttämättä käytä html:n kielen tunnistamiseen varattuja merkkauksia oikein, tai pohjaltaan esimerkiksi englanninkieliset sivut saattavat sisältää suomenkielisen keskustelupalstan. Internetistä löytyy hyvin suuri määrä erilaisia tekstidokumentteja, joissa ei ole juurikaan metadataa tai metadatan käyttäminen kielentunnistamiseen ei ole mahdollista.

Erityisen tarkka kielentunnistin mahdollistaisi automaattisesti kerättyjen tekstikorpusten laadun saattamisen aivan uudelle tasolle. Suuriin määriin tekstiä olisi automaattisesti merkattavissa esimerkiksi tekstin kielelle vierasperäisiä nimiä, jotka voivat haitata korpuksen avulla toteuttavaa tilastollista kielentutkimusta. Toisaalta vierasperäisten sanojen ja nimien käyttöä ja niiden levinneisyyttä olisi mahdollista tutkia suurista tekstimassoista aivan uudella tarkkuudella.

${ }^{23}$ https://gephi.org

24 http://suki.ling.helsinki.fi/wancaGephi

${ }^{25}$ https://github.com/raphv/gexf-js

${ }^{26}$ https://kansalliskirjasto.finna.fi/Record/fikka.5445333

27 https://github.com/uhdigihum/WancaPlatform 
Tunnistin suunniteltiin toteutettavan mahdollisimman laajalle joukolle kieliä, mutta erityispaino asetettiin harvinaisten suomalais-ugrilaisten kielten tunnistamiseen. Myös kielentunnistin oli tarkoitus julkaista GitHubissa avoimella lisenssillä josta se olisi siten kaikkien maailman kansalliskirjastojen ja muiden kieliteknologiaa hyödyntävien tahojen käytettävissä. Useita versioita kielentunnistimesta onkin projektin aikana ja sen jälkeen julkaistu, mutta yleensä ilman kielimalleja niiden suuren koon vuoksi. ${ }^{28}$ Verkkoharavointia varten kielentunnistimesta kehitettiin erillinen jatkuvasti toiminnassa oleva palvelinversio, jotta suuria kielimalleja ei tarvitsisi lukea keskusmuistiin aina uudelleen tunnistimen käynnistämisen yhteydessä.$^{29}$

Verkkosivut ovat käytännössä hyvin usein monikielisiä ja tämän vuoksi verkkosivujen tarkempaan kielentunnistukseen kehitettiin menetelmä monikielisten tekstien kielivalikoiman tunnistamiseksi. Menetelmä esiteltiin vuonna 2015 Kairossa järjestetyssä kansainvälisessä 'Intelligent Text Processing and Computational Linguistics" -konferenssissa ${ }^{30}$ (CICLing 2015) esitelmän ja posterin avulla [26]. Menetelmässä kuljetetaan tutkittavaa teksti-ikkunaa läpi tunnistettavan tekstin ja perättäisistä ikkunoista tunnistettujen kielten perusteella ja rajaarvoja käyttämällä tunnistetaan koko tekstin kielivalikoima. Yhdistettynä HeLI kielentunnistusmenetelmään on kehitetty kielivalikoiman tunnistin edelleenkin yksi parhaista tekstien kielivalikoiman päättelemiseksi [16]. Kielivalikoiman tunnistaminen monikielisistä teksteistä on kuitenkin selvästi hitaampaa kuin perinteinen yksikielinen kielentunnistus ja hankkeessa menetelmää käytettiinkin jo ladattuihin teksteihin, jolloin kyettiin poistamaan haravoinnin aikana virheellisesti tunnistettuja tekstejä [13,14].

Tunnistimen lisäksi tuotoksena kielentunnistukseen liittyvästä tutkimustyöstä oli työn alla T. Jauhiaisen väitöskirja kieliteknologian oppiaineeseen [16]. Yhdessä Krister Lindénin kanssa hän aloitti kielentunnistuksen menetelmiä koskevan katsausartikkelin valmistelun heti projektin alussa vuonna 2013. Monien vaiheiden jälkeen katsausartikkeli yhdistettiin toisen, kansainvälisen tutkijaryhmän katsausartikkelin kanssa marraskuussa 2017. Vuosien 2018 ja 2019 aikana T. Jauhiainen johti kansainvälisen tutkijaryhmän työtä artikkelien yhdistämisessä, päivittämisessä sekä vertaisarvioinnin parannusehdotusten tekemisessä. Elokuussa 2019 tähän asti laajin katsaus (108 sivua) tekstin kielen automaattisesta tunnistamisesta julkaistiin avoimesti Journal of Artificial Intelligence Research lehdessä [31]. Vuonna 2018 arXiv palvelussa julkaistu ${ }^{31}$ ja vertaisarviointiin lähetetty versio oli T. Jauhiaisen vuonna 2019 valmistuneen artikkeliväitöskirjan ensimmäinen artikkeli.

T. Jauhiaisen väitöskirjaan sisällytettiin lisäksi neljä tekstin kielen tunnistamisen menetelmien kehittämiseen keskittyvää artikkelia vuosilta 2015-2017. Kolme ensimmäistä artikkelia kuvasivat menetelmiä, joita projektin tutkijat olivat kehittäneet ja käyttäneet osallistuessaan kansainvälisiin tekstin kielen tunnis-

${ }^{28}$ https://github.com/tosaja/HeLI

${ }^{29}$ https://github.com/tosaja/TunnistinPalveluFast

30 https://www.cicling.org/2015/

31 https://arxiv.org/abs/1804.08186 
tukseen liittyviin kilpailuihin, joita järjestettiin VarDial työpajojen yhteydessä $[45,34,41]$. Vuoden 2015 "Discriminating between Similar Languages" -kilpailussa (DSL 2015) piti erotella kuuteen läheisiä kieliä sisältävään ryhmään sijoittuvan 13 kielen välillä sekä havaita myös tunnistimelle ennestään tuntemattomia kieliä. Tutkijat osallistuivat kilpailuun SUKI-nimisenä ryhmänä ja sijoittuivat neljännelle sijalle [18]. Seuraavana vuonna vastaava kilpailu (DSL 2016) järjestetiin uudelleen ja siinä nyt HeLI:ksi nimetty kielentunnistusmenetelmä menestyi erityisen hyvin, sijoittuen jaetulle ensimmäiselle sijalle [27]. T. ja H. Jauhiainen osallistuivat Osakassa järjestettyyn työpajaan ja esittelivät siellä kielentunnistintaan posterin avulla. Tutkijaryhmä osallistui myös vuoden 2017 kilpailuun, mutta siinä menestys jäi edellistä heikommaksi [28].

Neljäs artikkeli keskittyi vertailemaan kielentunnistusmenetelmien tarkkuutta vaikeissa tilanteissa [29]. Artikkelissa vertailtiin yhteensä seitsemää menetelmää siten että kielentunnistimien harjoitusaineisto oli kunkin kielen osalta mahdollisimman erilaista (out-of-domain) suhteessa testiaineistoon. Kaikki menetelmät kuvailtiin katsausartikkeliin suunnitellulla uudella matemaattisella notaatiolla. Myös testattavien kielten suuri määrä lisäsi tunnistustilanteen vaikeutta. Menetelmien piti valita kieli yhteensä 285 eri kielen joukosta, sisältäen useita harvinaisia uralilaisia kieliä. Artikkelissa todistetaan että tunnistusmenetelmä joka toimii hyvin pienelle joukolle kieliä, ei välttämättä toimi lainkaan hyvin suurelle määrälle kieliä. Osa kielistä oli myös erittäin lähellä toisiaan. Esimerkiksi suomen kielen tunnistus oli nyt merkittävästi hankalampaa koska kielivalikoimasta löytyivät nyt myös sekä kveeni että meänkieli. ${ }^{32}$ Neljäs kielentunnistusta vaikeuttava tekijä oli testattavien tekstien lyhyt pituus. Lyhyimmillä $5-25$ merkin pituisilla teksteille parhaiten kielen tunnisti Aalto-yliopistossa kehitetty tunnistin [40], mutta HeLI-menetelmään perustuva tunnistin pärjäsi parhaiten sitä pidemmillä teksteillä saavuttaen $\mathrm{F}-$ mitan $^{33} 99,5$ jo 60 merkin mittaisille teksteille.

T. Jauhiainen jatkoi kielentunnistuksen menetelmien kehittämistä myös väitöskirjaan liitettävien artikkelien jälkeen. Projektissa kehitettiin uusi mukautuvia kielimalleja käyttävä kielentunnistusmenetelmä, jonka avulla projektin tutkijat voittivat selvästi vuoden 2018 VarDial -työpajan yhteydessä järjestetyt "German Dialect Identification" (GDI 2018) sekä "Indo-Aryan Language Identification" (ILI) kilpailut [20,21]. Uusi tunnistusmenetelmä ei kuitenkaan ollut ylivoimainen kaikenlaisissa tilanteissa ja menestys "Discriminating between Dutch and Flemish in Subtitles" -kilpailussa ei ollut yhtä suurta [19]. Uutta menetelmää esiteltiin työpajassa Santa Fe:ssä elokuussa 2018 [42]. Toukokuussa 2019 T. Jauhiainen puolusti väitöskirjaansa Language Identification in Texts Helsingin yliopistossa vastaväittäjänään Nikola Ljubešić [16]. Vuonna 2019 projektin tutkijat voittivat kansainvälisen perinteisillä merkeillä kirjoitetun kiinan kielen tunnistuskilpailun "Discriminating between the Mainland and Taiwan variation of Mandarin Chinese" [22]. Käytännössä kaikki VarDial 5 yhteydessä järjestetyt kielentunnistuskilpailut voitettiin käyttämällä mukautuvia kielimalleja, joi-

32 http://suki.ling.helsinki.fi/LILanguages.html

${ }^{33}$ F-mitta on tarkkuuden ja palautuksen harmoninen keskiarvo. 
den inspiraationa oli projektin tutkijoiden vuoden 2018 kilpailumenestys [43]. Mukautuvia kielimalleja käyttävästä menetelmästä kirjoitettiin erillinen artikkeli Natural Language Engineering lehteen, jossa se julkaistiin avoimesti elokuussa 2019 [30].

\subsection{Olemassa olevien kielikorpusten inventaario}

Kielentunnistimen kielimallien rakentamiseen sekä tunnistimen toimivuuden evaluointiin tarvitaan tekstikorpuksia kaikilla tunnistimen ymmärtämillä kielillä. Osana tutkimustyötä oli tarkoitus kartoittaa mahdollisia käytettävissä olevia valmiita korpuksia. Kielentunnistimen kehitystyön ohessa oli Wikipedian artikkelikokoelmista luotu tekstikorpukset 264 kielelle. Yhtenä tavoitteena oli saattaa nämä tekstikorpukset mahdollisimman laajasti kielentutkijoiden käytettäväksi FIN-CLARINin ja CSC:n Kielipankin kautta. Vaikka tekstikorpukset olikin jo luotu, oli niiden laatua vielä syytä tarkastaa ennen niiden julkaisemista. Tarkastamisessa oli tarkoitus käyttää hyödyksi hankkeessa rakennettavaa kielentunnistinta. T. Jauhiaisen Pro gradu -tutkielman ohella rakennettua tunnistinta oli jo osin käytetty korpusten laadun parantamisessa esimerkiksi englanninkielisen tekstin poistamisessa muunkielisistä korpuksista. Käytännössä näin tehtiinkin, mutta lopputuloksena oli kuitenkin nimenomaan tämän projektin verkkoharavoinnin kielentunnistuksen tarpeisiin räätälöityjä ja harvinaisten uralilaisten kielten löytämiseen optimoituja korpuksia. Uralilaisten kielten löytämisen kannalta ei ollut väliä esimerkiksi sillä että joidenkin muiden kielten korpukset sisälsivät suuria määriä englantia. Projektin luomista Wikipediaan perustuvista ei-uralilaisista korpuksista ei katsottu olevan hyötyä myöskään sen vuoksi että Wikipedioista luotuja tekstikorpuksia julkaistiin samanaikaisesti muiden toimesta. Esimerkiksi Leipzigin yliopiston korpuskokoelmasta löytyy tekstejä tällä hetkellä jo 252 kielelle [35]. ${ }^{34}$ Pienimuotoista yhteistyötä tehtiin myös Leipzigin yliopiston kanssa heidän kokoelmiensa laadun parantamiseksi.

Kielentunnistimen rakentamisessa oli tarve erityisesti tekstikorpuksille niillä pienillä suomalais-ugrilaisilla kielillä, joilla ei ollut vielä lainkaan kirjoitettu Wikipedia-artikkeleita tai kirjoitettujen artikkelien tekstimäärä oli liian pieni kielimallien rakentamiseksi. Löydetyistä kielikorpuksista ja niiden käyttökelpoisuudesta kielentunnistuksen tarpeisiin oli ajatuksena kirjoittaa erillinen artikkeli. Olemassa olevien kieliaineistojen inventaarion suunniteltiin valmistuvan vuoden 2013 loppuun mennessä. Käytännössä internetistä löytyvän aineiston kielentunnistukseen sopivia korpuksia löytyi kuitenkin yllättävän vähän. Iso osa projektin käyttämistä tekstilähteistä on listattu taulukkoon, ${ }^{35}$ joka julkaistiin osana 2017 Nodalida-konferenssissa esitettyä tutkimusta [29]. Useille harvinaisemmille kielille saatiin aineistoa Jack Rueterin Koneen Säätiön rahoittamalta AKU-projektilta (Avointa kieliteknologiaa uralilaisille vähemmistökielille "Open-source Language Technology for Uralic Minority Languages"). ${ }^{36}$ Näistä kielistä mainittakoon inkeroinen, hanti, komi ja nenetsi.

\footnotetext{
${ }^{34}$ https://corpora.uni-leipzig.de

35 http://suki.ling.helsinki.fi/LILanguages.html

${ }^{36}$ https://blogs.helsinki.fi/fennougrica/2014/06/09/kuprina/
} 
Projektin alkaessa vastaavia harvinaisten useiden uralilaisten kielten internetaineistojen laajaan keräämiseen keskittyneitä hankkeita ei ollut olemassa, mutta projektin ollessa käynnissä Timofey Arkhangelskiy aloitti projektin vastaavanlaisten korpusten keräämisestä erityisesti internetin sosiaalisen median palveluista [1]. Hänen projektinsa perustui kohdesivustojen paikallistamiseen olemassaolevia hakukoneita käyttäen, sisältöjen manuaaliseen tarkasteluun ja sivustokohtaisten rajapintojen käyttämiseen aineiston lataamisessa. Tällaisten rajapintojen takana olevien tekstien löytäminen ei projektimme käyttämälle verkkoharavalle ollut useinkaan mahdollista, mikä tekee projekteista toisiaan hyvin täydentäviä. Arkhangelskiyn projektissa muodostetut korpukset löytyvät web-corpora.net ${ }^{37}$ sekä bitbucket.org ${ }^{38}$ palveluista $[1,2]$.

\subsection{Suomalais-ugrilaisten kielten virke-, lause- sekä sanakorpukset}

Yhtenä hankkeen tarkoituksista oli automaattista haravointia ja kielentunnistusta käyttäen luoda avoimia virke-, lause- ja sanakorpuksia uralilaisille kielille. Uusien tekstikorpusten saattaminen tutkijoiden käyttöön mahdollistaisi ja edistäisi uutta kielitieteellistä tutkimusta. Korpuksia ja niiden tekstin laatua on mahdollista automaattisesti siivota ja tarkastaa muilla olemassa olevilla kieliteknologisilla välineillä. Sanakorpuksista tuotettavat sanalistat olisivat hyödynnettävissä myös leksikografiseen työhön. Tekijänoikeuskysymysten selvittämisen jälkeen korpukset oli tarkoitus käyttöönasetettaa FIN-CLARIN:n Kielipankin kautta ja mahdollisuuksien mukaan ne julkaistaisiin avoimella Creative Commons lisenssillä.

Keväällä 2019 H. ja T. Jauhiainen rakensivat prosessin, jolla vuoden 2016 haravoinnin teksteistä muodostettiin virkekorpukset 29 uralilaiselle kielelle. Vuoden 2016 haravointi ei ollut uusi laaja haravointi vaan keskittyi tallentamaan ajantasaiset versiot jo Wanca palvelussa olleista linkeistä. Wanca 2016 korpukset julkaistiin elokuussa 2019 (RDHum, Oulu) sekä artikkelin että esitelmän avulla [13]. Wanca-portaali on liitetty osaksi FIN-CLARIN konsortion ylläpitämän Kielipankin työkalutarjontaa ${ }^{39}$ ja virkekorpukset ovat avoimesti kaikkien tutkijoiden käytettävissä Kielipankin Korp- ${ }^{40}$ ja Lataus-palveluissa. ${ }^{41}$ Korp-palvelu tarjoaa erillisen hakukäyttöliittymän, jonka kautta voi hakea esimerkiksi tiettyjen sanojen konkordansseja kun taas Lataus-palvelusta korpukset ovat saatavissa pelkkinä virkkeitä sisältävinä tekstitiedostoina sekä Korpista tuotettuna VRT-tiedostona. Toiveenamme on, että nämä korpukset toimisivat aineistona uralilaisten kielten tutkimukselle ja kieliteknologian kehittämiselle [37]. Esimerkiksi ersän ja komin korpuksia voisi käyttää jo kehitettyjen tai kehitteillä olevien puupankkien laajentamiseen $[39,38]$.

\footnotetext{
$\overline{37}$ http://volgakama.web-corpora.net/index_en.html

38 https://bitbucket.org/tsakorpus/tsakorpus/src/master/

39 https://www.kielipankki.fi/tyokalut/

${ }^{40}$ http://urn.fi/urn:nbn:fi:lb-2019052401

41 http://urn.fi/urn:nbn:fi:lb-2020022901
} 


\section{Projektin pitkä häntä}

Tässä luvussa käymme ensin lävitse projektin tulosten pohjalta jo toteutuneita uudempia tutkimuksia sekä tuotoksia ja sen jälkeen esittelemme joitakin keskeneräisempiä osaprojekteja.

\subsection{Uudempia tutkimuksia ja tuotoksia}

Vuonna 2020 tutkimusryhmän jäsenet julkaisivat prosessikuvauksen siitä miten vähemmistökielille kannattaa rakentaa verkosta kerättyjä tekstikorpuksia [14]. Kuvauksessa käydään lävitse prosessiin kuuluvia osa-alueita kuten verkkoharavointia, kielentunnistusta, joukkoistamista ja virkkeiden sekä lyhenteiden tunnistusta. Prosessissa käytetyt ohjelmistot julkaistiin myös avoimeisti GitHubissa. ${ }^{42}$ Määriteltyä prosessia käyttäen tutkimusryhmän jäsenet käsittelivät vuonna 2017 haravoituja sivuja. Vuoden 2016 haravoinnin tavoin tämä keräys oli keskittynyt Wanca palvelussa jo olleiden linkkien tekstien uudelleenlataamiseen. Uuden materiaalin määrä suhteessa Wanca 2016 korpukseen ei tämän vuoksi ollut merkittävä, mutta uutta tekstiä löytyi kuitenkin sen verran että oli mahdollista muodostaa kohtuullisen laaja vain uusia virkkeitä sisältävä osa-aineisto. Wanca 2016 korpusta ja uutta Wanca 2017 osa-aineistoa käyttäen tutkimusryhmä suunnitteli aivan uudenlaisen testiasetelman VarDial työpajojen ohessa järjestettäviä kielentunnistukseen keskittyviä "shared task"-kilpailuja varten. Niinkuin aikaisemmin jo mainitsimmekin, näitä kilpailuja oli järjestetty vuodesta 2014 alkaen ja tutkimusryhmän jäsenet olivat ansiokkaasti osallistuneet vuosittain vuodesta 2015 lähtien "SUKI"-nimisenä joukkueena [44,45,34,41,42,43]. Vuonna 2019 he olivat myös itse järjestäneet yhden kilpailuista. Kilpailu, "Cuneiform Language Identification" (CLI), keskittyi nuolenpäillä kirjoitettujen akkadin- ja sumerinkielisten tekstien murteiden tunnistamiseen [17]. Vuoden 2020 kilpailu nimettiin "Uralic Language Identification" (ULI) ja se keskittyi erityisesti harvinaisten uralilaisten kielten tekstipätkien tunnistamiseen isosta määrästä tekstiä, joka oli kirjoitettu enimmäkseen muilla kuin uralilaisilla kielillä [25]. Kilpailu jakautui kolmeen alakilpailuun, joista erityisesti ensimmäisessä ja toisessa oli tarkoituksena kyetä tunnistamaan oikein nimenomaan uralilaisilla kielillä kirjoitettua tekstiä. Testiaineistona käytetyistä Wanca 2017 korpuksen osa-aineistosta ja Leipzigin yliopiston korpuksista löytyi hyvin erilaisia määriä eri kieliä ja jotkin harjoitusaineistossa esiintyneet uralilaiset kielet puuttuivat sieltä kokonaan. Tuloksia heikensi se jos uralilaisia kieliä ei tunnistettu oikein sekä jos muita kieliä tunnistettiin väärin uralilaisiksi kieliksi. Ensimmäisessä alakilpailussa kaikki harvinaiset (29 kieltä mutta ei suomi, viro tai unkari) uralilaiset kielet olivat yhdenvertaisia riippumatta niiden esiintymien määrästä ja toisessa alakilpailussa esiintymien määrällä taas oli merkitystä mikä teki esimerkiksi pohjoissaamesta merkittävästi tärkeämmän kuin vaikkapa inkeroisesta. Kolmas alakilpailu pisteytti myös kaikki muut 149 kieltä ja olikin näin kielimäärältään laajin tähän mennessä järjestetty kielentunnistukseen keskittyvä kilpailu.

$\overline{42}$ https://github.com/uhdigihum/SUKISentencePipeline

In Hämäläinen, M., Partanen, N., Alnajjar, K. (eds.) Multilingual Facilitation (2021), pages 228-247. -- CC BY 4.0 
Kilpailu osoittautui erittäin haastavaksi, toisaalta epätavallisen testiasetelman ja toisaalta suurten harjoituskorpusten osalta. Ainoastaan Kanadan kansallisen tutkimuskeskuksen tutkimusryhmä onnistui tuottamaan tuloksia kilpailuun käyttäen BERT pohjaisia syväoppivia menetelmiä [9], joilla sama tutkimusryhmä oli voittanut 2019 järjestetyn CLI kilpailun [5,43]. Heidän tuloksensa jäivät kuitenkin merkittävästi SUKI-projektin tuottamista vertailutuloksista [4]. Vertailutulokset oli saatu käyttäen suoraan vuonna 2017 julkaistun HeLItunnistimen parametrejä [29]. Pienen osallistujamäärän vuoksi päätettiin kilpailua jatkaa siten, että perustettiin erillinen sivusto ${ }^{43}$ jossa ylläpidettäisiin kilpailuun osallistuvien ryhmien parhaita tuloksia [10]. Seuraava VarDial työpaja päätettiin järjestää 2021 EACL konferenssin yhteydessä huhtikuussa, joka tarkoitti sitä että seuraavat kielentunnistuskilpailut alkoivat hyvin nopeasti edellisen joulukuussa 2020 järjestyn työpajan jälkeen. Myös ULI hyväksyttiin jälleen mukaan viralliseksi VarDial kilpailuksi ja ennen VarDial kampanjan määräaikaa siihen osallistuivat kanadalaisen tutkimusryhmän ("NRC") lisäksi myös italialainen ("Phlyers") ja belgialainen ("LAST") tutkimusryhmä [8]. NRC onnistui merkittävästi parantamaan BERT-pohjaista kielentunnistintaan, mutta ei kuitenkaan sitä käyttäen saavuttanut HeLI-tunnistimen vertailutuloksia. Myös italialainen tutkimusryhmä kokeili syväoppivien neuroverkkojen käyttöä, mutta artikkelissaan he toteavat että eivät onnistuneet rakentamaan sellaista järjestelmää joka olisi kyennyt hallitsemaan kielten suuren määrän ja kielienväliset erot harjoistusaineiston määrässä [7]. Sen sijaan yhdistäen SVM ja Naive Bayes menetelmiä he onnistuivat ylittämään ensimmäisen alakilpailun vertailutulokset. BERT-pohjaisten mallien lisäksi NRC ryhmä päätti myös käyttää aikaisemmin rakentamaansa Naive Bayes-pohjaista kielentunnistinta jonka avulla he onnistuivat tuottamaan tähän mennessä parhaat tulokset ensimmäiselle ja toiselle alakilpailulle [6].

Tutkimusryhmä osallistui myös itse joihinkin muihin VarDial 2020 ja 2021 työpajan yhteydessä järjestettyihin kielentunnistuskilpailuihin. Vuonna 2020 he osallistuivat romanian murteiden erotteluun keskittyvään kilpailuun (Romanian Dialect Identificatiion, "RDI") sekä uudentyyppiseen sosiaalisen median viestien paikantamiskilpailuun (Social Media Variety Geolocation, "SMG"). Menestys ei ollut tällä kertaa suuren suuri ja ainoastaan SMG kilpailun Balkanilaisiin kieliin keskittyvässä alakilpailussa päästiin edes kolmannelle (kuudesta joukkueesta) sijalle [10,23]. Vuoden 2021 kilpailussa tutkimusryhmän jäsenet osallistuivat uudelleen RDI kilpailuun sekä uutena kilpailuna esiteltyyn dravidakieliin keskittyneeseen kilpailuun (Dravidian Language Identification, "DLI"). T. Jauhiainen osallistui DLI kilpailuun kansainvälisessä ryhmässä, sijoittuen toiselle sijalle [32]. SUKI-joukkue sen sijaan voitti ylivoimaisesti RDI 2021 kilpailun käyttäen mukautuvia kielimalleja Naive Bayes tunnistimen yhteydessä [24].

$\overline{43}$ http://urn.fi/urn:nbn:fi:lb-2020102201 


\subsection{Keskeneräisiä tutkimuksia}

Tätä artikkelia kirjoittaessa Wanca 2017 korpus odottaa edelleen varsinaista julkaisuaan. Käytännössä Wanca 2017 on koottu ja valmiina, mutta sitä ei ole haluttu julkaista niin kauan kuin ULI 2020/2021 kilpailuun voi osallistua sillä se tulee käytännössä sisältämään kilpailun oikeat vastaukset. Korpus on tarkoitus julkaista Kielipankin Korp- ja Lataus-palveluiden kautta kunhan ULI 2020/2021 kilpailu suljetaan. ULI 2020/2021 kilpailu on ajateltu pidettävän auki niin kauan kuin sitä kohtaan on kiinnostusta tai kun tutkimusryhmä saa koottua uuden testiaineiston kilpailun seuraavalle versiolle.

Projektin vuonna 2018 suorittama verkkokeräys erosi vuosien 2016 ja 2017 keräyksestä siten että se oli oikea laajamittainen harvointi, jossa käytiin kokonaan lävitse useita kansainvälisiä internet-domaineja etsien projektin kohdekielillä kirjoitettua aineistoa. Verkkokeräyksen löytämät ja tallentamat tekstit ovat edelleen tallessa, mutta niitä ei ole vielä lainkaan jatkokäsitelty. Vuoden 2021 aikana on tarkoitus prosessoida ladatut aineistot projektissa kehitetyn työnkulun mukaisesti alkaen siitä että löydettyjen sivujen osoitteet ladataan Wancaan, jossa joukkoistuksen avulla niiden kieliä tarkastetaan. Näin luotavan Wanca 2018 korpuksen uusista virkkeistä muodostetaan uusi testiaineisto vuoden 2022 ULI kilpailulle. Myös Jack Rueter on liittynyt mukaan Wanca 2018/ULI2022 tuottajajoukkioomme.

Yhtenä tavoitteenamme on ollut julkaista yleiskäyttöinen kielentunnistin joka olisi vaivatonta ja helppoa ottaa käyttöön, mutta käytännössä sitä ei vielä ole tehty. Kaikki projektin eri tutkimuksia varten rakennetut tunnistimet ovat olleet hyvin räätälöityjä kyseisen tutkimuksen tarpeisiin erityisesti käytettyjen kielimallien osalta eivätkä ne sellaisenaan sovellu yleiskäyttöisen tunnistimen käytettäviksi. Osana Vaikuttavuussäätiön rahoittamaa "Language Identification of Speech and Text" -hanketta aiomme nyt vihdoin keskittyä myös aivan yleiskäyttöisten kielimallien rakentamiseen ja julkaisemiseen.

\section{$5 \quad$ Loppupäätelmät}

Projektissa on onnistuttu jatkokehittämään ns. perinteisiä kielentunnistuksen menetelmiä ja osin projektin tulosten ansiosta perinteiset mentelmät ovat onnistuneet kilpailemaan ja usein jopa voittamaan uusinta syväoppimistekniikkaa käyttävät menetelmät. Monilla muilla kieliteknologian osa-alueilla perinteisten luokittelumenetelmien edistäminen on viime vuosina jäänyt vaille suurta huomiota syväoppimisen tuottaessa ylivoimaisia tuloksia.

Projekti on tuottanut korpuksia harvinaisille uralilaisille kielille ja niitä käyttäen luonut uudenlaisen kielentunnistukseen liittyvän kilpailun jossa keskitytään erityisesti ongelmiin joita kohdataan kun harvinaisilla vähemmistökielillä kirjoitettuja tekstejä etsitään automaattisesti internetistä. Kansainvälinen kilpailu on myös osaltaan lisännyt harvinaisten uralilaisten kielten tunnettuutta kieliteknologian ja koneoppimisen tutkimusaloilla. 


\section{Kiitokset}

Haluamme kiittää kaikkia projektin toimintaan osallistuneita uralilaisten kielten asiantuntijoita, mainittakoon heistä tässä Jack Rueter, Niko Partanen, Sulev Iva, Ilja Moshnikov, Julia Normanskaja, Michael Rießler, Trond Trosterud ja Tommi Pirinen. Helsingin yliopiston tietotekniikkaosaston henkilöstö ansaitsee myös kiitokset pitkällisestä yhteistyöstä projektin käyttämän palvelinympäristön suunnittelussa, hankinnassa ja ylläpitämisessä. Kiitokset Janne Markkanen, Iivari Leppälä, Seppo Syrjänen, Arsi Moilanen, Ville Tenhunen, Eero Kesälä sekä Minna Harjuniemi.

Kielentunnistuksen ja verkkoharavoinnin kehittäminen ei olisi myöskään ollut mahdollista ilman läheistä ja pitkäaikaista yhteistyötä Kansalliskirjaston kanssa. Pitkäaikaisesta ja edelleen jatkuvasta yhteistyöstä kiitämme Kristiina Hormiaa, Kaisa Kaunosta, Esa-Pekka Keskitaloa, Johanna Liljaa, Leena Saarista, Aija Vahtolaa sekä Petteri Veikkolaista.

Kieliteknologian oppiaineen kotimaiset ja ulkomaiset yhteistyökumppanit ansaitsevat myös omat erityiskiitoksensa: Marcos Zampieri, Jörg Tiedemann, Timothy Baldwin, Marco Lui, Atro Voutilainen, Nikola Ljubešić, Yves Scherrer, Jyrki Niemi, Jussi Piitulainen, Erik Axelson, Mietta Lennes, Hanna Westerlund ja Anssi Yli-Jyrä. Kiitokset teille kaikille.

Kiitämme myös erityisesti Kansalliskirjaston Jussi-Pekka Hakkaraista, joka ensimmäisenä esitteli Koneen Säätiön kieliohjelman työryhmän jäsenille. Erityiskiitokset kuuluvat myös projektin suunnittelua ja työtä vahvasti tukeneille Kimmo Koskenniemelle ja Lauri Carlsonille. Kiitos myös Koneen Säätiölle kieliohjelmasta ja projektimme rahoittamisesta.

\section{Viitteet}

1. Arkhangelskiy, T.: Corpora of social media in minority uralic languages. In: Proceedings of the Fifth International Workshop on Computational Linguistics for Uralic Languages. pp. 125-140. Association for Computational Linguistics, Tartu, Estonia (Jan 2019). https://doi.org/10.18653/v1/W19-0311, https://www.aclweb.org/anthology/W19-0311

2. Arkhangelskiy, T.: Web corpora of volga-kama uralic languages. Finno-Ugric Languages and Linguistics 9(1-2) (2020)

3. Bastian, M., Heymann, S., Jacomy, M.: Gephi: an open source software for exploring and manipulating networks. In: Proceedings of the International AAAI Conference on Web and Social Media. vol. 3 (2009)

4. Bernier-Colborne, G., Goutte, C.: Challenges in neural language identification: NRC at VarDial 2020. In: Proceedings of the 7th Workshop on NLP for Similar Languages, Varieties and Dialects. pp. 273-282. International Committee on Computational Linguistics (ICCL), Barcelona, Spain (Online) (Dec 2020), https://www.aclweb.org/anthology/2020.vardial-1.26

5. Bernier-Colborne, G., Goutte, C., Léger, S.: Improving cuneiform language identification with BERT. In: Proceedings of the Sixth Workshop on NLP for Similar Languages, Varieties and Dialects. pp. 17-25. Association for Computational Linguistics, Ann Arbor, Michigan (Jun 2019). https://doi.org/10.18653/v1/W191402, https://www.aclweb.org/anthology/W19-1402 
6. Bernier-Colborne, G., Léger, S., Goutte, C.: N-gram and Neural Models for Uralic Language Identification: NRC at VarDial 2021. In: Proceedings of the Eighth Workshop on NLP for Similar Languages, Varieties and Dialects (VarDial) (2021)

7. Ceolin, A.: Comparing the performance of CNNs and shallow models for language identification. In: Proceedings of the Eighth Workshop on NLP for Similar Languages, Varieties and Dialects (VarDial) (2021)

8. Chakravarthi, B.R., Găman, M., Ionescu, R.T., Jauhiainen, H., Jauhiainen, T., Lindén, K., Ljubešić, N., Partanen, N., Priyadharahsini, R., Purschke, C., Rajagopal, E., Scherrer, Y., Zampieri, M.: Findings of the VarDial Evaluation Campaign 2021. In: Proceedings of the Eighth Workshop on NLP for Similar Languages, Varieties and Dialects (VarDial) (2021)

9. Devlin, J., Chang, M.W., Lee, K., Toutanova, K.: Bert: Pre-training of deep bidirectional transformers for language understanding (2019)

10. Gaman, M., Hovy, D., Ionescu, R.T., Jauhiainen, H., Jauhiainen, T., Lindén, K., Ljubešić, N., Partanen, N., Purschke, C., Scherrer, Y., Zampieri, M.: A report on the VarDial evaluation campaign 2020. In: Proceedings of the 7th Workshop on NLP for Similar Languages, Varieties and Dialects. pp. 1-14. International Committee on Computational Linguistics (ICCL), Barcelona, Spain (Online) (Dec 2020), https://www.aclweb.org/anthology/2020.vardial-1.1

11. Jauhiainen, H.: Verkkoharavoinnin menetelmiä (2013), bachelor thesis, University of Helsinki

12. Jauhiainen, H., Jauhiainen, T., Lindén, K.: The Finno-Ugric Languages and The Internet Project. Septentrio Conference Series 0(2), 87-98 (2015). https://doi.org/10.7557/5.3471

13. Jauhiainen, H., Jauhiainen, T., Linden, K.: Wanca in Korp: Text corpora for underresourced Uralic languages. In: Jantunen, J., Brunni, S., Kunnas, N., Palviainen, S., Västi, K. (eds.) Proceedings of the Research data and humanities (RDHUM) 2019 conference. pp. 21-40. No. 17 in Studia Humaniora Ouluensia, University of Oulu, Finland (2019)

14. Jauhiainen, H., Jauhiainen, T., Lindén, K.: Building web corpora for minority languages. In: Proceedings of the 12th Web as Corpus Workshop. pp. 23-32 (2020)

15. Jauhiainen, T.: Tekstin kielen automaattinen tunnistaminen. Master's thesis, University of Helsinki, Helsinki (2010)

16. Jauhiainen, T.: Language identification in texts. Ph.D. thesis, University of Helsinki, Finland (2019)

17. Jauhiainen, T., Jauhiainen, H., Alstola, T., Lindén, K.: Language and dialect identification of cuneiform texts. In: Proceedings of the Sixth Workshop on NLP for Similar Languages, Varieties and Dialects. pp. 89-98. Association for Computational Linguistics, Ann Arbor, Michigan (Jun 2019). https://doi.org/10.18653/v1/W191409, https://www.aclweb.org/anthology/W19-1409

18. Jauhiainen, T., Jauhiainen, H., Lindén, K.: Discriminating Similar Languages with Token-based Backoff. In: Proceedings of the Joint Workshop on Language Technology for Closely Related Languages, Varieties and Dialects, LT4VarDial '15. pp. 44-51. Hissar, Bulgaria (2015)

19. Jauhiainen, T., Jauhiainen, H., Lindén, K.: HeLI-based Experiments in Discriminating Between Dutch and Flemish Subtitles. In: Proceedings of the Fifth Workshop on NLP for Similar Languages, Varieties and Dialects (VarDial). pp. 137-144. Santa Fe, NM, USA (2018)

20. Jauhiainen, T., Jauhiainen, H., Lindén, K.: HeLI-based experiments in Swiss German dialect identification. In: Proceedings of the Fifth Workshop on NLP for Si- 
milar Languages, Varieties and Dialects (VarDial 2018). pp. 254-262. Association for Computational Linguistics, Santa Fe, New Mexico, USA (Aug 2018), https://www.aclweb.org/anthology/W18-3929

21. Jauhiainen, T., Jauhiainen, H., Lindén, K.: Iterative language model adaptation for Indo-Aryan language identification. In: Proceedings of the Fifth Workshop on NLP for Similar Languages, Varieties and Dialects (VarDial 2018). pp. 66-75. Association for Computational Linguistics, Santa Fe, New Mexico, USA (Aug 2018), https://www.aclweb.org/anthology/W18-3907

22. Jauhiainen, T., Jauhiainen, H., Lindén, K.: Discriminating between Mandarin Chinese and Swiss-German varieties using adaptive language models. In: Proceedings of the Sixth Workshop on NLP for Similar Languages, Varieties and Dialects. pp. 178-187. Association for Computational Linguistics, Ann Arbor, Michigan (Jun 2019). https://doi.org/10.18653/v1/W19-1419, https://www.aclweb.org/anthology/W19-1419

23. Jauhiainen, T., Jauhiainen, H., Lindén, K.: Experiments in language variety geolocation and dialect identification. In: Proceedings of the 7th Workshop on NLP for Similar Languages, Varieties and Dialects. pp. 220-231. International Committee on Computational Linguistics (ICCL), Barcelona, Spain (Online) (Dec 2020), https://www.aclweb.org/anthology/2020.vardial-1.21

24. Jauhiainen, T., Jauhiainen, H., Lindén, K.: Naive Bayes-based Experiments in Romanian Dialect Identification. In: Proceedings of the Eighth Workshop on NLP for Similar Languages, Varieties and Dialects (VarDial) (2021)

25. Jauhiainen, T., Jauhiainen, H., Partanen, N., Lindén, K.: Uralic language identification (ULI) 2020 shared task dataset and the wanca 2017 corpora. In: Proceedings of the 7th Workshop on NLP for Similar Languages, Varieties and Dialects. pp. 173-185. International Committee on Computational Linguistics (ICCL), Barcelona, Spain (Online) (Dec 2020), https://www.aclweb.org/anthology/2020.vardial-1.16

26. Jauhiainen, T., Lindén, K., Jauhiainen, H.: Language Set Identification in Noisy Synthetic Multilingual Documents. In: Proceedings of the Computational Linguistics and Intelligent Text Processing 16th International Conference (CICLing 2015). pp. 633-643. Cairo, Egypt (2015)

27. Jauhiainen, T., Lindén, K., Jauhiainen, H.: HeLI, a word-based backoff method for language identification. In: Proceedings of the Third Workshop on NLP for Similar Languages, Varieties and Dialects (VarDial3). pp. 153162. The COLING 2016 Organizing Committee, Osaka, Japan (Dec 2016), https://www.aclweb.org/anthology/W16-4820

28. Jauhiainen, T., Lindén, K., Jauhiainen, H.: Evaluating HeLI with Non-Linear Mappings. In: Proceedings of the Fourth Workshop on NLP for Similar Languages, Varieties and Dialects. pp. 102-108. Valencia, Spain (2017)

29. Jauhiainen, T., Lindén, K., Jauhiainen, H.: Evaluation of Language Identification Methods Using 285 Languages. In: Proceedings of the 21st Nordic Conference on Computational Linguistics (NoDaLiDa 2017). pp. 183-191. Linköping University Electronic Press, Gothenburg, Sweden (2017)

30. Jauhiainen, T., Lindén, K., Jauhiainen, H.: Language model adaptation for language and dialect identification of text. Natural Language Engineering 25(5), 561-583 (2019)

31. Jauhiainen, T., Lui, M., Zampieri, M., Baldwin, T., Lindén, K.: Automatic Language Identification in Texts: A Survey. Journal of Artificial Intelligence Research 65, 675-782 (2019), https://doi.org/10.1613/jair.1.11675 
32. Jauhiainen, T., Ranasinghe, T., Zampieri, M.: Comparing Approaches to Dravidian Language Identification. In: Proceedings of the Eighth Workshop on NLP for Similar Languages, Varieties and Dialects (VarDial) (2021)

33. Kone Foundation: The language programme 2012-2016 (2012), https://koneensaatio.fi/en/language-programme/

34. Malmasi, S., Zampieri, M., Ljubešić, N., Nakov, P., Ali, A., Tiedemann, J.: Discriminating between similar languages and Arabic dialect identification: A report on the third DSL shared task. In: Proceedings of the Third Workshop on NLP for Similar Languages, Varieties and Dialects (VarDial3). pp. 1-14. The COLING 2016 Organizing Committee, Osaka, Japan (Dec 2016), https://www.aclweb.org/anthology/W16-4801

35. Richter, M., Quasthoff, U., Hallsteinsdóttir, E., Biemann, C.: Exploiting the leipzig corpora collection. In: Proceedings of the Information Society Language Technologies Conference. Ljubljana (2006)

36. Rueter, J., Hämäläinen, M.: Synchronized mediawiki based analyzer dictionary development. In: Proceedings of the Third Workshop on Computational Linguistics for Uralic Languages. pp. 1-7. Association for Computational Linguistics, St. Petersburg, Russia (Jan 2017). https://doi.org/10.18653/v1/W17-0601, https://www.aclweb.org/anthology/W17-0601

37. Rueter, J., Partanen, N.: On new text corpora for minority languages on the helsinki korp.csc.fi server. In: Электронная письменность народов Российской Федерации: опыт, проблемы и перспективы. р. 32-36 (2019)

38. Rueter, J., Partanen, N., Ponomareva, L.: On the questions in developing computational infrastructure for Komi-permyak. In: Proceedings of the Sixth International Workshop on Computational Linguistics of Uralic Languages. pp. 1525. Association for Computational Linguistics, Wien, Austria (10-11 Jan 2020), https://www.aclweb.org/anthology/2020.iwclul-1.3

39. Rueter, J., Tyers, F.: Towards an open-source universal-dependency treebank for Erzya. In: Proceedings of the Fourth International Workshop on Computational Linguistics of Uralic Languages. pp. 106-118. Association for Computational Linguistics, Helsinki, Finland (Jan 2018). https://doi.org/10.18653/v1/W18-0210, https://www.aclweb.org/anthology/W18-0210

40. Vatanen, T., Väyrynen, J.J., Virpioja, S.: Language Identification of Short Text Segments with N-gram Models. pp. 3423-3430. Valletta, Malta (2010)

41. Zampieri, M., Malmasi, S., Ljubešić, N., Nakov, P., Ali, A., Tiedemann, J., Scherrer, Y., Aepli, N.: Findings of the VarDial evaluation campaign 2017. In: Proceedings of the Fourth Workshop on NLP for Similar Languages, Varieties and Dialects (VarDial). pp. 1-15. Association for Computational Linguistics, Valencia, Spain (Apr 2017). https://doi.org/10.18653/v1/W17-1201, https://www.aclweb.org/anthology/W17-1201

42. Zampieri, M., Malmasi, S., Nakov, P., Ali, A., Shon, S., Glass, J., Scherrer, Y., Samardžić, T., Ljubešić, N., Tiedemann, J., van der Lee, C., Grondelaers, S., Oostdijk, N., Speelman, D., van den Bosch, A., Kumar, R., Lahiri, B., Jain, M.: Language identification and morphosyntactic tagging: The second VarDial evaluation campaign. In: Proceedings of the Fifth Workshop on NLP for Similar Languages, Varieties and Dialects (VarDial 2018). pp. 1-17. Association for Computational Linguistics, Santa Fe, New Mexico, USA (Aug 2018), https://www.aclweb.org/anthology/W18-3901

43. Zampieri, M., Malmasi, S., Scherrer, Y., Samardžić, T., Tyers, F., Silfverberg, M., Klyueva, N., Pan, T.L., Huang, C.R., Ionescu, R.T., Butna- 
ru, A.M., Jauhiainen, T.: A report on the third VarDial evaluation campaign. In: Proceedings of the Sixth Workshop on NLP for Similar Languages, Varieties and Dialects. pp. 1-16. Association for Computational Linguistics, Ann Arbor, Michigan (Jun 2019). https://doi.org/10.18653/v1/W19-1401, https://www.aclweb.org/anthology/W19-1401

44. Zampieri, M., Tan, L., Ljubešić, N., Tiedemann, J.: A report on the DSL shared task 2014. In: Proceedings of the First Workshop on Applying NLP Tools to Similar Languages, Varieties and Dialects. pp. 58-67. Association for Computational Linguistics and Dublin City University, Dublin, Ireland (Aug 2014). https://doi.org/10.3115/v1/W14-5307, https://www.aclweb.org/anthology/W145307

45. Zampieri, M., Tan, L., Ljubešić, N., Tiedemann, J., Nakov, P.: Overview of the DSL shared task 2015. In: Proceedings of the Joint Workshop on Language Technology for Closely Related Languages, Varieties and Dialects. pp. 19. Association for Computational Linguistics, Hissar, Bulgaria (Sep 2015), https://www.aclweb.org/anthology/W15-5401 